\title{
PERANCANGAN SISTEM AKSES PERSONEL MENGGUNAKAN SPEECH RECOGNITION
}

\author{
Ariyawan Sunardi ${ }^{1)}$, Djoko Hari Nugroho ${ }^{2)}$ \\ ${ }^{1)}$ Prodi Teknik Elektro UNPAM \\ Jln. Puspiptek Raya No 46 Buaran, Setu - Tangerang Selatan 15310 \\ ${ }^{2)}$ Prodi Teknik Elektro - ISTN \\ ${ }^{1)}$ Email : dosen00332@unpam.ac.id
}

\begin{abstract}
ABSTRAK
Pengenalan personel dalam meningkatkan keamanan sebuah objek menjadi hal yang penting. Berbagai metode digunakan untuk pengenalan personel melalui alat bantu kartu maupun biometrik. Suara merupakan biometrik populer yang dapat diterapkan dalam hardware. Telah dilakukan perancangan pengenalan personel menggunakan fasilitas Graphic User Interface (GUI) Matlab R2010a. Tujuan penelitian ini untuk mendesain system pengenalan personel dimulai dari input speech sampai output identitas personel. Sampel suara dengan frekuensi mono $8000 \mathrm{~Hz}$ dan 8 bit per sampel ditangkap melalui mikrophon kemudian dismpan sebagai file .wav. Sampel suara kemudian dilakukan proses pre prosesing melalui dekomposisi. Selanjutnya identifikasi personel menggunakan fasilitas fuzzy dari software Matlab. Identias personel disimpan sebagai database sebagai data uji terhadap file suara input. Didapatkan database 10 personel yang direkam masing-masing sebanyak 5 kali. Untuk pengujian dilakukan 10 kali dengan file suara yang berbeda diperoleh keberhasilan $70,00 \%$ dan rata-rata running time terlama 6,832 detik.
\end{abstract}

Kata kunci : pengenalan personel, GUI, Matlab, speech recognition, safety dan security.

\section{ABSTRACT}

Personnel Access System Design For Safety And Security Using Speech Recognition Identification. The introduction of personnel in increasing the security of an object is important. Various methods are used for the introduction of personnel through card and biometric tools. Sound is a popular biometric that can be applied in hardware. The design of the introduction of personnel using the Graphic User Interface (GUI) facility Matlab R2010a has been carried out. The purpose of this study is to design a personnel recognition system starting from input speech to the output of personnel identity. Sound samples with mono $8000 \mathrm{~Hz}$ frequencies and 8 bits per sample are captured through microphones and then saved as .wav files. Sound samples are then subjected to a pre-processing process through decomposition. Furthermore, identification of personnel uses fuzzy facilities from the Matlab software. Personality standards are stored as databases as test data against input sound files. A database of 10 personnel was recorded each of 5 times. For testing carried out 10 times with different sound files $70.00 \%$ success was achieved and the longest running time was 6.832 seconds.

Keywords : personnel identification, GUI, Matlab, speech recognition, safety and security 


\section{PENDAHULUAN}

Speech recognition adalah proses pengenalan suara manusia yang dilakukan oleh komputer. Suara merupakan salah satu sistem biometrik yang paling popular dan mudah dalam penerapan hardware. Suara manusia tidak dapat dikenali begitu saja ketika dimasukkan ke dalam komputer. Sinyal suara manusia yang diterima melalui mikropon berupa sinyal analog sehingga harus diubah menjadi sinyal digital.

Dari sinyal digital yang didapat, diperlukan beberapa tahap untuk mengenalnya, diantaranya adalah pre prosesing, ekstrasi fitur dan pengenalan pola. Pre prosesing dilakukan untuk mendapatkan ciri dasar dari sinyal suara. Dalam ekstraksi fitur digunakan transformasi terhadap suara untuk mengubah domain waktu pada suara menjadi domain frekuensi. Pencarian pola dilakukan dengan membandingkan data kata personel yang ada di basis data dan menentukan pola yang paling cocok dengan suara tersebut.

Salah satu penerapan speech recognition adalah identifikasi personel berdasarkan suara personel tersebut yang telah ada di database. Penulis melihat adanya peluang pengembangan sistem akses personel untuk menjamin keselamatan dan keamanan suatu instalasi. Pengembangan sistem ini melalui penerapan speech recognition. Dalam penelitian ini dibatasi pada sistem identifikasi personel dan adanya false alarm untuk menjamin keselamatan dan keamanan. Ide untuk merancang sistem speech recognition yang menggunakan transformasiwavelet sebagai ekstraksi fitur dan neuro fuzzy sebagai metode klasifikasi.

\section{TEORI}

\section{Speech Recognition}

Speech Recognition atau pengenalan suara menjadi salah satu hal potensial yang menjadi perhatian interaksi antara manusia dan komputer. Desain dari sistem Speech Recognition membutuhkan perhatian dan penanganan khusus karena terdapat beberapa kendala : realisasi akustik fonem, keragaman akustik, keragaman pengucapan/dialek bahasa, kondisi emosional pembicara, kecepatan berbicara dan lingkungan.

\section{Pemrosesan Sinyal Digital}

Sinyal digital berbeda dengan sinyal analog karena sudah disampled dan diquantized. Keduanya membatasi berapa banyak informasi yang ada di sinyal digital. Pengolahan sinyal digital adalah pemrosesan sinyal yang mempunyai kaitan dengan penyajian perubahan bentuk dan manipulasi dari sisinya dan informasi dalam bentuk digital.

Proses pengubahan gelombang suara menjadi data digital ini dinamakan Analogto-Digital Conversion (ADC), dan kebalikannya, pengubahan data digital menjadi gelombang suara dinamakan Digital-to-Analog Conversion (DAC).

\section{Preprosesing Sinyal}

Dalam tahapan preprosesing, semua sinyal suara yang pertama dikonversi ke tingkat sampling $8 \mathrm{kHz}$ dengan resolusi 16-bit.Dalam prakteknya, suara pembicara akan terkontaminasi dengan komponen noise/gangguan.Kondisi rekaman suara, perangkat maupun lingkungan bertindak sebagai tambahanpengganggu sumber yang tidak diketahui. Oleh karena itu, perlu disaring oleh sinyal digital penyaringan sebagai pra-pengolahan untuk analisis dan klasifikasi suara pembicara.

$$
X=F S \cdot d t(\text { detik }) \cdot\left(\frac{\text { bit }}{8}\right) \cdot j
$$


neuro fuzzy. Hasil dari software Matlab R2010a ini yag akan kembali memberikan identifikasi personel. Hasil dari identifikasi dengan masukan file wav dari masingmasing personel sebanyak 5 kali akan digunakan menjadi database.

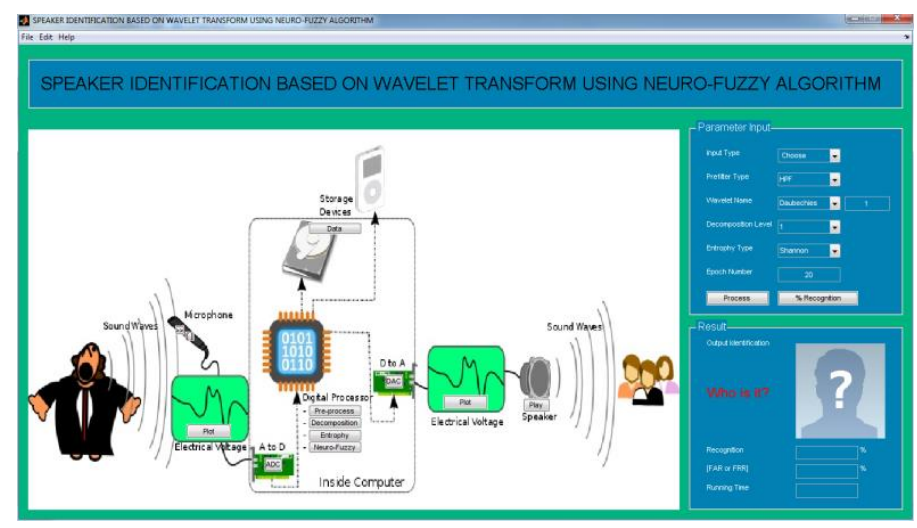

Gambar 2. Tampilan Antarmuka Pengguna Secara Grafis

Untuk pengujian, file file suara yang telah ada dimasukkan ke dalam PC untuk diolah oleh software Matlab R2010a yang akan mengahsilkan identitas personel. Hal ini dilakukan dengan 10 kali percobaan. Didapatkan hasil seperti pada Tabel 2.

Tabel 2. Pengujian Dengan File Suara Personel Yang Sama

\begin{tabular}{|c|l|l|}
\hline No. & File suara ke & Berhasil / tidak \\
\hline 1. & Personel 1-1 & Berhasil \\
\hline 2. & Personel 1-2 & Tidak \\
\hline 3. & Personel 1-3 & Berhasil \\
\hline 4. & Personel 1-4 & Berhasil \\
\hline 5. & Personel 1-5 & Berhasil \\
\hline 6. & Personel 1-1 & Tidak \\
\hline 7. & Personel 1-2 & Berhasil \\
\hline 8. & Personel 1-3 & Tidak \\
\hline 9. & Personel 1-4 & Berhasil \\
\hline 10. & Personel 1-5 & Berhasil \\
\hline
\end{tabular}

Selain itu juga diuji tingkat kecepatan sistem untuk mengenali personel yang bersangkutan. Disini faktor Personel Computer (PC) sangat menentukan. Adapun PC yang dgunakan memiliki prosesor Intel Pentium CPU P6300 @ $2,27 \mathrm{GHz} \& 2,26 \mathrm{GHz}$, RAM $2 \mathrm{~GB}$. Hasil pengujian juga ditunjukkan tingkat prosentase pengenalan personel.

Tabel 3. Pengujian Waktu Pengenalan

\begin{tabular}{|c|c|c|}
\hline $\begin{array}{c}\text { Level } \\
\text { Dekomposisi }\end{array}$ & $\begin{array}{c}\text { Running Time } \\
\text { (detik) }\end{array}$ & $\begin{array}{c}\text { Tingkat } \\
\text { Pengenalan } \\
\text { (\%) }\end{array}$ \\
\hline \hline 1 & 0,998 & 14,55 \\
\hline 2 & 2,046 & 51,82 \\
\hline 3 & 3,232 & 82,73 \\
\hline 4 & 4,814 & 98,18 \\
\hline 5 & 6,832 & 100,00 \\
\hline
\end{tabular}

Didapatkan untul pengenalan $100 \%$ memerlukan waktu selama 6,832 detik dengan menggunakan level dekomposisi tertinggi yaitu 5 .

\section{KESIMPULAN}

Berdasarkan hasil penelitian tersebut, maka dapat disimpulkan sebagai berikut : Telah dibuat sistem perancangan sistem akses personel menggunakan speech recognition. Tingkat keberhasilan pengujian file suara terhadap database didapatkan $70 \%$. Dan untuk mengenali secara penuh $100 \%$ memerlukan waktu 6,832 detik menggunakan level dekomposisi 5.

\section{DAFTAR PUSTAKA}

1. Anny Tandyo, Martono, Adi Widyatmoko. 2005. Speaker Identification Menggunakan Transformasi Wavelet Diskrit Dan Jaringan Saraf Tiruan Back- 
Propagation.Jakarta : Universitas

Bina Nusantara

2. Ariman. 2008. Pengklasifikasian

Modulasi Digital PSK Berbasis

Entropi Shannon Menggunakan

Wavelet. Jakarta : ISTN

3. Ashish Kumar Panda, Amit Kumar

Sahoo. 2011. Study Of Speaker Recognition Systems.Departement Of Electronics And Communications National Institute Of Technology, Rourkela

3. A.Vijay kumar, Aruna, M.Vijayapal Reddy. 2011. A Fuzzy Neural Network for Speech Recognition. India : ARPN Journal of Systems and Software

4. Binanto, Iwan. 2010. Multimedia Digital Dasar Teori dan Pengembangannya. Yogyakarta: Andi.

6. Intan Verona. 2006. Perbandingan Tingkat Akurasi Antara Algoritma Momentum Back Propagation dan Learning vector Quantization Neural Network Untuk Speech Recognition. Jakarta : Universitas Tarumanegara

5. Joseph P. Campbell, Jr. Speaker Recognition. IEEE : Department of Defense Fort Meade.

7. Ni Wayan Sumartini Saraswati.Transformasi Wavelet Dan Thresholding Pada Citra Menggunakan Matlab. Universitas Udayana : Jurnal GENERIC. 